\title{
Baanbrekers
}

\section{Die groot skeiding}

\author{
Felix Bosch
}

\section{INLEIDING}

Die Groot Skeiding is die verhaal, en nie 'n tegniese verslag nie, van een van die grootste wetenskaplike en tegniese prestasies in die geskiedenis van Suid-Afrika. Dit is die vertelling van die sukses van 'n klein span Suid-Afrikaners, wat onder leierskap van dr. W.L. Grant 'n unieke proses vir isotoopskeiding, en gevolglik uraanverryking, ontwerp, ontwikkel en vervolmaak het. In omvang en kompleksiteit oorskadu hierdie prestasie alle ander, insluitend hartoorplantings.

Hierdie span toegewyde baanbrekers het met 'n karige begroting tot hulle beskikking nogtans in 'n relatiewe kort tydperk daarin geslaag om uit te voer wat tot op daardie tydstip slegs deur die groot moondhede Rusland, Sjina, Amerika, Engeland, Frankryk en Duitsland gedoen is. Hierdie lande het groot spanne wetenskaplikes, ingenieurs en tegnici gehad en het beskik oor onbeperkte begrotings en alle nodige toerusting en geriewe.

In hierdie verhaal, wat die tydperk van ongeveer 1962 tot 1966 dek, is menslike, wetenskaplike, tegniese, politiese en ekonomiese aspekte feitlik onskeibaar saamgevleg. Die doel is hoofsaaklik om 'n eerlike weerspieëling van sommige van die dag tot dag aktiwiteite van die spanlede te gee.

Die destydse Eerste Minister, B.J. Vorster, kondig op 20 Julie 1970 in die Volksraad aan:

Suid-Afrikaanse wetenskaplikes het daarin geslaag om 'n nuwe proses vir uraanverryking te ontwikkel sowel as die geweldige gepaardgaande tegnologie en hulle is tans besig met die oprigting van 'n kleinskaalse aanleg vir die verryking van uraan wat op hierdie proses gebaseer is. Suid-Afrikaanse wetenskaplikes het hiermee weereens roem vir Suid-Afrika verwerf. Hulle het in die verlede al onvergeetlike bydraes tot die wetenskap gelewer maar miskien is hierdie een wat ek vandag aankondig ongeëwenaard in die geskiedenis van die land.

Koerante het gereageer met voorbladberigte van die Eerste Minister se aankondiging. Drr. Roux en Grant het gesamentlik die H.F. Verwoerd-toekenning ontvang, en dr. Grant het ook die Havengaprys vir Ingenieurswese, die Toekenning vir Verdienstelikheid van die S.A. Raad vir Professionele Ingenieurs, die Ordeteken van die Suiderkruis (Goud) en erelidmaatskap van die S.A. Instituut vir Meganiese Ingenieurs ontvang.

As gevolg van 'n gebrek aan kennis van, en begrip vir die aard, omvang en kompleksiteit van die deurbraak, het die algemene publiek skaars kennis geneem van hierdie prestasie. Omtrent almal weet wat 'n hartoorplanting is en het 'n redelike begrip waaroor dit gaan. Aan die ander kant is daar min mense wat weet van die ingewikkeldheid en geweldige probleme wat gepaard gaan met die verryking van uraan deur middel van isotoopskeiding. Om dus bewus te wees van die bykans onoorkombare probleme wat met die deurbraak gepaard gegaan het, is dit 'n voorvereiste om 'n begrip te hê van dié ontsaglike prestasie wat die pioniers behaal het.

Die destydse Eerste Minister, B.J. Vorster, het tydens die aankondiging ook gesê:

These two scientists - a complementary team - who have been associated for 22 years in the service of science in South Africa, have through their combined effort and guidance made possible this important development - a development which nevertheless never would have succeeded had it not been for the real contribution (in some cases very important), zeal and loyalty of the personnel who were associated with the project.

Weens die aard van die projek is meeste van die spanlede se betrokkenheid by die projek nooit geopenbaar nie. Die gasverkoelingprojek is as uiters geheim geklassifiseer en gevolglik het die gesinne en vriende van spanlede geen benul gehad van waarmee hulle geliefdes doenig was nie. Pa's soos ek, moes wit leuens vertel as hulle kinders gevra het "wat doen pa by die werk, juffrou wil weet?" Ek het maar gesê ek is 'n assistent-wielklopper se handlanger.

Die gasverkoelingprojek is moontlik die enigste, maar beslis die grootste en belangrikste projek waar uitsluitlik Afrikaans as voertaal gebruik is. Afrikaans is deurgaans gebruik vir alle kommunikasie met betrekking tot die projek. Behalwe vir enkele briewe aan die buiteland, het alle briefwisseling in Afrikaans plaasgevind. Samesprekings, memoranda, omsendbriewe, verslae, spesifikasies, tekeninge, instruksiehandleidings ensovoorts het slegs in Afrikaans verskyn. Dit het vereis dat 'n isotoopskeiding- en verrykingsterminologie daargestel moes word. Ook name vir die verskeie komponente van toerusting wat ontwerp en vervaardig is, moes geskep word.

\section{EK AANVAAR DIENS BY DIE RAAD OP ATOOM- KRAG}

Vroeg in 1962, terwyl ek nog onderwyser was aan die destydse Pretoriase Tegniese Kollege, is ek genooi na 'n onderhoud met dr. W.L. Grant. Die RAK se kantore was toe nog in Merino, die Wolraad se gebou, wat eers die Oxford kafee-bioskoop gehuisves het en waar ek dikwels in my jong dae Westerns gaan kyk het. Op die dag van die onderhoud het ek by die RAK aangemeld. Dr. Grant het agter sy lessenaar gesit en aan sy linkerkant het dr. Wynand de Villiers gesit. Dr. Wally Grant was op hierdie tydstip hoofingenieur en dr. De Villiers 'n kernfisikus wat onlangs uit die buiteland teruggekeer het. Met die bekendstellings agter die rug het dr. Grant verduidelik dat my onsuksesvolle aansoek vroeër om die pos van skakelbeampte op lêer geplaas is, en gevra of ek sou belangstel in 'n pos as ontwerptekenaar by die RAK. Sonder huiwering het ek positief gereageer. Dr. Grant het verduidelik wat my pligte sou wees, en dr. De Villiers het kortliks sy rol in die kerningenieurs- 
weseprogram verduidelik. Hierdie was 'n nuwe gebied van die ingenieurswese in Suid-Afrika, en die vooruitsigte om daarby betrokke te wees het my geweldig geprikkel. Toe die brief van die RAK aankom, het ek alreeds instinktief geweet dat ek die pos gekry het. Ek het skriftelik bevestig dat ek die pos aanvaar, en my bedanking by my destydse werkgewer ingedien.

Op 1 Julie 1962 het ek by die personeelafdeling van die RAK aangemeld. Nadat ek die toepaslike vorms voltooi het, is ek op 'n begeleide toer van die kantore geneem, aan al die personeellede voorgestel, en na die tekenkantoor geneem, wat maar karig toegerus was. Op hierdie stadium was daar alreeds 'n natrekker/tekenaar, Elize Smuts-Erasmus, werksaam by die RAK. Sy was werksaam in die afdeling wat die oprigting van die SAFARI-1-reaktor te Pelindaba gemoniteer het, by John Colley, Chris Moller en Rob Barbour.

Sekere kantore en fasiliteite van die RAK was "Geheim" geklassifiseer en omdat ons in 'n gebou was waar die publiek toegang gehad het, moes ons 'n geslote-deur-beleid handhaaf. Die destydse hoof van sekuriteit, genl.maj. Els, het beklemtoon dat kantoordeure gesluit moes word wanneer die kantoor verlaat word, al is dit vir slegs vyf minute. Ons het die generaal dopgehou en toe hy eendag sy kantoor verlaat het sonder om die deur te sluit, het ons sy kantoor gesluit en 'n aantal van die personeel gekry om op die trappe weg te kruip en te wag vir die generaal se terugkoms. Toe hy agterkom dat sy kantoordeur gesluit is, het ons almal hande geklap. Hy was glad nie ingenome nie en het ons gedreig met aksie omdat ons die gereg gedwarsboom het.

Dr. De Villiers het my op 'n toer van die ander fasiliteite van die RAK geneem. In 'n voorafvervaardigde laboratorium in Proesstraat het Kobus Muller navorsing op elektromagnetiese pompe gedoen. Die pompe sou gebruik word om natrium te pomp vir die kragreaktorkonsep. Die volgende halte was by persele wat voorheen gebruik is deur 'n motoronderdelewinkel, in Du Toitstraat, met die naam Northern Tyres and Accessories. Al die reklameplakkate van motoronderdele wat teen die mure was, is daar gelaat as deel van die doeltreffende vermomming. Die voorste deel van die perseel was 'n werkwinkel met hoëakkuraatheiddraaibanke en freesmasjiene. Ek is voorgestel aan die hoof van die werkwinkel, Johnnie Fourie, die voormaninstrumentmaker Jan Rijneke, instrumentmaker Dick O'Grady en oom Willie Liebenberg, skrynwerker en algemene vakman.

Die pakkamer van die winkel is omskep in 'n laboratorium. Dit was 'n hoogs geklassifiseerde gebied, en slegs persone met spesiale klaring is in dié laboratorium toegelaat. Dr. Grant se broer W.W. (Bill) Grant het in die laboratorium gewerk.

My eerste taak in die tekenkantoor was om 'n aantal A0deursnitte vir die reaktorkonsepverslag, wat in die parlement ter tafel gelê moes word, te teken. Ek moes baie ure oortyd werk om die sperdatum vir die verslag te haal.

Die RAK het nog nie geriewe gehad om afdrukke van tekeninge te maak nie, maar het 'n ooreenkoms met die Departement van Openbare Werke (DOW) gehad om van hulle geriewe gebruik te mak. Die DOW was destyds in die Aktegebou op die hoek van Bosman- en Vermeulenstraat, gehuisves. Ek moes persoonlik die tekeninge na die DOW neem, en bystaan terwyl die afdrukke gemaak is. Bedorwe afdrukke moes vernietig word. Die afdrukke moes van die seminat-tipe wees, aangesien dr. Grant uiters allergies was vir die ammoniaktipe.

Hierdie tekeninge was as 't ware my vuurdoop. Soos vir enige konsep was daar dikwels veranderinge, en om 'n inkop-papier-tekening met fyn detail en arsering te verander is moeilik en frustrerend. Uiteindelik is die tekeninge en die verslag voltooi en dr. Grant het toe almal wat 'n aandeel daaraan gehad het, vir koffie geneem na 'n klein Hollandse kafee, Chez Mori in Burlington-deurloop.

Die volgende taak in die tekenkantoor was die ontwerp van 'n subkritiese samestelling om die neutron-vloeddigtheid oor die deursnit van die brandstofelemente vir die kragreaktorkonsep te stip. Die steierwerk om die uiters swaar brandstofelemente te ondersteun moes van aluminium gemaak word, en was dus onder hoë spanning. 'n Prototipe is gemaak en deur die SABS getoets deur 'n ekwivalente massa bakstene te gebruik. Die laterale en wringdefleksie is vasgestel deur middel van 'n reeks klokmeters.

\section{HUISVESTING IN SHAMROCKGEBOU}

In Oktober 1963 word daar besluit om die boonste twee verdiepings van die Shamrockgebou op die hoek van Skinneren Potgieterstraat, van die stadsraad van Pretoria te huur. Hierdie gebou sou drie jaar later gesloop word vir die Skinnerstraatdeurpad. Die grondvloer was beset deur besighede insluitende Shamrock Kafee, wat baie gerieflik was om 'n ligte ete te geniet of om 'n koeldrank te koop. Die grondvloergedeelte van die trapput en deel van die ingangsportaal is afgeskort en gebruik as kompressorkamer. Die afskortings was nie klankdig nie en die geluid was uiters irriterend, met die gevolg dat die mees gesogte kantore dié was wat die verste van die kompressor was. Die ingangsportaal het ook gedien as bergingsruimte vir die swaar en lomp gassilinders. Hierdie silinders moes trappe op na die laboratorium deur die tegnici gedra word.

Die laboratoria en 'n paar kantore was op die eerste vloer geleë, en die tweede vloer was slegs kantore, toilette en 'n klein kombuisie. Dr. de Villiers was gebouhoof en sy kantoor was op die eerste vloer; langsaan was sy sekretaresse, me. Venter, se kantoor. Geen naamborde is aangebring op die straatingange om aan te dui wie die huurders is nie. Elke persoon wat in die gebou gewerk het, is voorsien van 'n sleutel om toegang tot die gebou te verkry.

Die gasverkoelingsprojek was buite perke vir almal behalwe diegene betrokke by die projek, en hulle is voorsien van sleutels om toegang te verkry. Op hierdie tydstip het die navorsingspan bestaan uit dr. Wally Grant (spanleier), dr. Immo Bock (wetenskaplike), Bill Grant (tegnikus en later wetenskaplike), Robbie Sinclair (tegnikus), Hendrik Boshoff (tegnikus), Chris de Jager (tegnikus), en die werkwinkelpersoneel. Dr. de Villiers en Kobus Muller het ook toegang tot die laboratorium gehad. Slegs enkele van die topbestuur van die destydse RAK het magtiging gehad om die laboratorium te besoek. Uitsonderings was dr. A.J.A. Roux (direkteur), dr. T.E.W. Schumann (adjunkvoorsitter van die raad), dr. J.P.B. Hugo (hoof van fisiese metallurgie) en dr. R.E. Robinson (hoof van ekstraksiemetallurgie).

J.J. Human was in beheer van alle administrasie insluitende aankope vir die gasverkoelingsprojek. Sy eintlike taak was om ekonomiese studies ten opsigte van kernkrag en kernbrandstof te onderneem; hiervoor het hy 'n doktoraat ontvang. Die tekenkantoorpersoneel is uitgebrei deur die aanstelling van Jack Boon (tekenaar), Barry van Niekerk (senior tekenaar) en Meka Mulder-Boerrigter (natrekker). Hierdie tekenkantoor was die kern van die RAK se ontwerpaktiwiteite en werk is vir alle afdelings van die RAK onderneem.

Almal wat in die gebou werksaam was, het op die eerste vloer in die hoek van die gang teetye bymekaar gekom. Hierdie byeenkomste het gereeld ontaard in grapsessies met baie gekskeerdery. Op verjaarsdae en ander belangrike geleenthede sou die betrokkene koek of eetgoed voorsien. Op dr. Grant se verjaardag in Augustus het hy 'n brandewyntert, wat sy vrou Anna gemaak het, gebring en gesê "geniet dit mense, my een 
en twintig jaar KWV-brandewyn is in dié tert". Die groepie het oor die algemeen goed klaargekom alhoewel die verdeelde sekerheidsreëlings wel 'n mate van spanning veroorsaak het.

Etenstye is die gebou in 'n slagveld verander, en verskeie ernstige spelle brug is uitgespook in verskillende lokale. $\mathrm{Na}$ etenstyd het post mortems van die spelle plaasgevind, met lang verduidelikings oor hoe die spel eintlik gespeel moes gewees het.

Daar was ook ongelukkig 'n paar treurige voorvalle, soos byvoorbeeld die afloerder in die dames se toilet; by etlike geleenthede het die afloerder vanaf 'n aangrensende hokkie 'n dame afgeloer. Geen dame was dapper genoeg om net op te staan en die deur te sluit nie, en gevolglik is die afloerder nooit betrap nie. 'n Ander onplesierige voorval was toe geld uit een van die dames se handsak gesteel is. Alhoewel die persone werksaam in die gebou onder verdenking geplaas is, was dit nie noodwendig iemand in die gebou wat die geld geneem het nie. Die straatdeur was met tye nie gesluit nie, en teetye het almal hulle kantore verlaat.

\section{SEKONDERING AAN DIE GASVERKOELINGPROJEK}

In 'n gesprek met Doc Wally, soos dr. Grant alom bekend was, het hy 'n keuse aan my gestel: Ek kon of in die hoof-RAKtekenkantoor aanbly en heel waarskynlik hoof van 'n baie groot tekenkantoor word (ek was toe waarnemende hoof), of gesekondeer word om 'n spesiale tekenkantoor vir die gasverkoelingprojek op die been te bring. Ek het sonder huiwering besluit op die laasgenoemde opsie. Doc Wally het gesê ons sal die aangeleentheid verder bespreek sodra my sekerheidsklaring vir toegang tot die GVP ontvang is.

Omtrent 'n maand later was ek geklaar en Doc Wally het die sekondering aan die GVP met my verder bespreek. Ek moes 'n projektekenkantoor tot stand bring om ontwerpe en werkstekeninge van die ingenieurs en wetenskaplikes se sketse, konsepte en idees daar te stel. Dit was 'n matriksaanstelling, vir administratiewe doeleindes sou ek aan die hoof van Tegniese Dienste (RAK) verantwoordelik wees, maar taakgewys sou ek direk aan Doc Wally rapporteer. In die begin was hierdie reëling aanvaarbaar maar met verloop van tyd het dit uiters problematies geword. Die hoofrede daarvoor was dat die senior personeel van Tegniese Dienste (wat my salaris en bevorderings beheer het) in meeste gevalle nie toegang tot die GVP gehad nie. Dit het onvermydelik my verhouding met die hoofde van Tegniese Dienste vertroebel. Ek moes by een geleentheid geweld gebruik om 'n ongemagtigde hoof uit die GVP-tekenkantoor te hou. Dit het onvermydelik tot my nadeel gestrek.

Doc Wally het verduidelik dat die GVP' $n$ navorsingsprojek was, wat toegespits is op die ondersoek, ontwerp, optimalisering en vervaardiging van elemente vir isotoopskeiding, ten einde uraan te verryk. Die vermoë om kernwapens te vervaardig is slegs terloops genoem. Dit is natuurlik algemene kennis dat vir kernbrandstof 3 tot $7 \%$ verrykte uraan gebruik word, maar om 'n kernwapen te maak vereis minstens $90 \%$ verryking.

Die vereiste vir algehele geheimhouding was dus absoluut noodsaaklik. Enige skimp dat die projek te doen het met isotoopskeiding, sou hewige reaksie van politici plaaslik en in die buiteland veroorsaak het. Die skuilnaam (GVP) moes die indruk skep dat die projek te doen het met die verkoelingsmedium van 'n kragreaktorkonsep waaraan daar destyds gewerk is. Die GVP was sonder twyfel 'n prestigeprojek. Die poste is nooit geadverteer nie, en persone is almal persoonlik genader om by die projek aan te sluit. Slegs landsburgers met die hoogste sekerheidsklaring, en wat bereid was om die eed van geheimhouding af te lê, is oorweeg vir aanstelling.

Die taalmedium vir alle kommunikasie ten opsigte van die
GVP (behalwe enkele briewe aan die buiteland) was Afrikaans. Afrikaanse terminologie vir isotoopskeiding en die betrokke komponente moes dus geskep word. Na bekendstelling van die projek is die terminologie deur onkundiges beskryf as 'n geheime kode of taal wat deur die lede van die projek gebruik is. Sover my navorsing kon vasstel, is die GVP die enigste projek wat aanspraak kan maak op die uitsluitlike gebruik van Afrikaans.

\section{DIE HOOFAKTIWITEITE IN SHAMROCKGEBOU}

Op hierdie tydstip het dr. Grant nog sy kantoor in Merinogebou gehad, maar gedurende normale werksure het hy ook tyd in die laboratorium in Shamrockgebou, met sy assistente Bill Grant en Robbie Sinclair, deurgebring. Doc Wally het ook saans tot laat, Saterdae, party Sondae en ook vakansiedae in die laboratorium gewerk. Ek beskou dit as algehele oorgawe aan die projek. Die spanwerk en toewyding kan nie onderskat word as 'n belangrike faktor vir die sukses van die projek nie. Dr. Immo Bock en sy assistente, Hendrik Boshoff en Chris de Jager, was ook besig in die laboratorium met navorsing op skeidingselemente.

As gevolg van my sekondering aan die GVP het ek die sentrale tekenkantoor verlaat en geskuif na 'n kantoor in die hoësekerheidsgedeelte van die gebou. Barrie van Niekerk is aangestel as hooftekenaar in die sentrale tekenkantoor. My eerste taak in die GVP-tekenkantoor was die ontwerp van 'n materiaaltoetssel vir dr. Conrad Johannes, die projek se metallurg. Die doel van hierdie stuk toerusting was om die effek van blootstelling aan uraanheksafluoried ( $\left.\mathrm{UF}_{6}\right)$, van 'n reeks materiaalmonsters, te ondersoek. Sorgvuldig voorbereide, gepoleerde en chemies gereinigde monsters van bepaalde massa is blootgestel aan $\mathrm{UF}_{6}$ teen beheerde druk en temperature tot $130^{\circ} \mathrm{C}$.

Die monsters is met gereelde tussenposes metallurgies ondersoek. Die eerste reeks monsters het bestaan uit sagte staal, vlekvrye staal, suiwer aluminium, verskeie aluminiumlegerings, beril-koper, monel (koper-nikkel-legering), nikkel, en aluminium-nikkel-brons. Hierdie toetse het belangrike inligting verskaf vir die ontwerp van toetstoerusting en fasiliteite vir die projek.

My volgende taak was om die ontwerp en konstruksie van 'n prototipe drukmeter te ondersoek wat geskik sou wees vir die uiters giftige en korrosiewe $\mathrm{UF}_{6}$-gas. Hierdie tipe drukmeter sou nodig wees vir toetse met $\mathrm{UF}_{6}$. Tot dusver was alle toetse daarop toegespits om die isotope van ligter gasse soos byvoorbeeld argon, neon, xenon en kripton te skei. Die twee hoofparameters wat ondersoek is in die verskillende ontwerpe van skeidingselemente, is skeidingsfaktore en skeidingsenergie. 'n Ligtegas-toetssamestelling het hoofsaaklik bestaan uit die skeidingselement (draaikolkbuis), 'n kompressor, drukmeters, rotameter-vloeimeters, en 'n massaspektrometer om isotoopkonsentrasies te bepaal. Hierdie komponente is almal in 'n toetsbank ingebou en met metaal- en plastiekbuise verbind.

My poging om 'n drukmeter te ontwerp en vervaardig, was nie 'n groot sukses nie. Ek het besluit op 'n helikale Bourdonbuistipe-drukmeter. Die Bourdonbuise van drukmeters wat destyds plaaslik in die handel beskikbaar was, is almal van koperlegerings, gewoonlik beril-koper, vervaardig. Hierdie metale is op daardie tydstip beskou as ongeskik vir $\mathrm{UF}_{6}$, en ek moes toe vlekvrye staal gebruik. Ek het 'n $8 \mathrm{~mm}$-binnedeursneebuis, $350 \mathrm{~mm}$ lank, met Cerromatrix ('n legering met 'n smeltpunt van $80^{\circ} \mathrm{C}$ ) gevul en die werkwinkel het hierdie buis afgedraai na ' $\mathrm{n}$ wanddikte van $0,25 \mathrm{~mm}$. Die Cerromatrix is nou met kookwater verwyder. ' $\mathrm{n}$ Vlekvryestaalstrook $0,5 \mathrm{~mm}$ dik vir die volle lengte, is in die buis geplaas. Die buis is nou deur 'n stel rollers plat gerol, en die vlekvryestaalstrook 
verwyder. Die buis is opgewen om 'n helikale Bourdonbuis te vorm. $\mathrm{Na}$ hittebehandeling en uitgloeiing is die buis op 'n bestaande drukmeterraam gesweis. Die drukmeter het gewerk maar ernstige histerese-afwykings getoon. Terwyl ek nog gewonder het hoe om hierdie probleem op te los, het ons nuus ontvang van 'n verskaffer in Frankryk, wat 'n reeks monel (koper-nikkel-legering) drukmeters beskikbaar het, wat ideaal was vir $\mathrm{UF}_{6}$-toepassings.

Die volgende saak wat aandag moes geniet was die ontwerp van kleppe geskik vir gebruik met $\mathrm{UF}_{6}$. Die hoofvereiste was dat sodanige kleppe geheel en al lekdig na die omgewing moes wees. Verskillende ontwerpe is oorweeg voordat 'n geskikte een aanvaar is. Dit was 'n baltipe klep van vlekvrye staal waarvan die stang deur middel van 'n ingevoerde konsertina (konvolusiebuis) aan die meganisme gesweis was, op so 'n wyse dat helium-lekdigtheid bewerkstellig is. Hierdie kleppe is voorsien van politetrafluooretileen (PTFE) afdigtingsvlakke, en gevolglik was hulle geskik vir beide vakuum- en druktoepassings. Hierdie kleppe is vervaardig deur 'n buitemaatskappy en het bekend gestaan as die HEA-kleppe. Hulle het 'n belangrike rol gespeel in toekomstige verrykingsaktiwiteite.

Die ligtegas-isotoopskeidingstoetse het onverpoos voortgegaan te midde van vriendelike mededinging tussen die spanne van Doc Wally en dr. Bock. Deurbrake, voorspellings, en alfas het die gesprekke in die laboratorium oorheers.

\section{DIE GASVERKOELINGPROJEK VERHUIS NA PELINDABA}

Middel 1964 is die RAK se administrasiegebou op die Pelindabaterrein, dertig kilometer wes van Pretoria, voltooi en het die personeel van die Merinogebou hulle nuwe kantore betrek. Die GVP is nog steeds in Shamrockgebou gehuisves en die werkwinkel in die perseel in Du Toitstraat. Vir die volgende ses maande was dit ietwat ongerieflik, veral vir vergaderings en byeenkomste. Personeel van Shamrock kon steeds van die vroeër vergunning aan RAK personeel, om middagetes in die kafeteria van die Departement van Arbeid in Laboriagebou te nuttig, gebruik maak.

Vroeg in Desember 1964 was die westelike vleuel van die reaktoringenieurswesegebou op die Pelindabaterrein gereed om betrek te word, en die verskuiwing van die GVP is haarfyn beplan. Al die toetsbanke en gepaardgaande toerusting sou afgetakel word en voor die Kersvakansie na Pelindaba vervoer word, waar dit onder streng bewaking geberg sou word tot na die Kersvakansie. Vroeg in Januarie 1965, direk na die Kersvakansie, sou die spanlede die toerusting aanmekaarsit en voortgaan met die eksperimentele werk.

Die Staatsgarage het vir die vervoer gesorg en gevolglik moes alles sorgvuldig gepak en bedek word. Die laboratoriumpersoneel en RAK-sekerheidspersoneel moes elke vrag na Pelindaba vergesel. Vroeg in Januarie 1965 met die Kersvakansie agter die rug, het die tegnici aan die werk gespring om die nuwe laboratoria gereed te maak om weer voort te gaan met die toetse. Die kompressor is nou in die kelder van die gebou geïnstalleer en met pype aan die toetsbanke verbind.

Die hele GVP is nou gerieflik saam in dieselfde gebou gehuisves, met die laboratoria, tekenkantoor, werkwinkel en kantore naby mekaar. Mnr. (later doktor) J.J. (Jannie) Wannenburg, hoof van kompressorontwikkeling en mnr. Melt van Schoor Hamman (wetenskaplike) sluit by die projek aan. Die RAK het 'n afleweringsdepot in Pretoria behou. Dit was geleë in die ou brandweerstasie in Minnaarstraat, en is beman deur oom Ligthelm. Goedere is hier afgelewer en dan gereeld na Pelindaba vervoer met RAK-voertuie.

\section{VERVOER TUSSEN PRETORIA EN PELINDABA}

Die feit dat Pelindaba omtrent vyf en dertig kilometer wes van Pretoria, waar meeste van die personeel woonagtig was, geleë is, was 'n faktor wat die projek noemenswaardig beïnvloed het. Personeel het oral gewoon, in Irene, Johannesburg en selfs Brits, en om personeel te kry waar hulle moes wees vir hulle verskeie aktiwiteite was inderdaad 'n logistieke nagmerrie. Die bestuurder van die vervoerafdeling, mnr. Botha was meer as opgewasse vir hierdie belangrike taak

Tydens die beplanningsfase van die Pelindabaterrein is daar gehoop en gespekuleer dat 'n aansienlike aantal van die personeel sou belangstel in huisvesting naby Pelindaba. Met hierdie veronderstelling in gedagte, is 'n lap grond oorkant die Pelindabaterrein deur 'n sakeman, mnr. Tolstoi Schoeman, aangekoop met die gedagte om 'n woongebied daar te vestig. As gevolg van 'n algehele gebrek aan belangstelling is die plan laat vaar. Die afwesigheid van geskikte skole en ander geriewe in die omgewing is aangevoer as die hoofrede vir dié houding. Dit sou meebring dat kinders Pretoria toe vervoer moes word om by skole uit te kom.

Die RAK het 'n kontrak met die destydse Pretoria Munisipaliteit gesluit om vervoer tussen Pretoria en Pelindaba deur middel van semiluukse busse te verskaf. Die skema het in 1964 begin met vier roetes, wat die gebied tussen Waterkloof in die suide en Waverley in die noorde gedek het. Daar was beperkte opklimpunte op die vier basiese roetes, en sommige passasiers moes deur familielede, vriende of saamryklubs soggens afgelaai word en saans weer opgepik word. Hierdie diens moes voortdurend uitgebrei word om die toenemende aantal personeellede te vervoer, sodat dit uiteindelik bestaan het uit een en dertig roetes wat Johannesburg en Brits ingesluit het.

Benewens die diens wat deur die stadsraad gelewer is het die RAK ook 'n bykomstige busdiens met hulle eie busse met vyf en twintig sitplekke gelewer. Busse het vertrek vanaf Kerkplein om 08:45 en 14:10 en van Pelindaba om 12:15. 'n Bus het om 16:15 smiddags vanaf Pelindaba vertrek en regstreeks Universiteit van Pretoria toe gery vir personeel wat klasse moes bywoon.

Omdat die GVP so vinnig as moontlik met die navorsing moes vorder, het die personeel vrywilliglik ingestem om langer ure te werk. Smiddags 'n uur langer tot 17:00 en twee aande per week tot 21:00. Die spanlede is vergoed vir hierdie addisionele tyd, maar dit was nie die oorwegende faktor nie. Dit het natuurlik bykomstige vervoerreëlings tot gevolg gehad. Daar was vier basiese, maar hoogs aanpasbare, roetes wat kruis en dwars oor Pretoria gestrek het, met die gevolg dat sekere lede eers na 22:00 tuisgekom het, nadat hulle 07:00 die oggend die huis verlaat het.

Doc Wally se toegewydheid teenoor die projek, sy geesdrif en aansporing en natuurlik sy besondere leierskapstyl wat eie aan hom is, het die spanlede gelukkig laat voel om 'n aandeel te hê aan die GVP. Sekere spanlede het op eie inisiatief naweke en vakansiedae kom werk. Dr. Grant het aanvanklik van die busvervoer gebruik gemaak, maar is later voorsien met 'n Volkswagen, en nog later met 'n Holden vir sy persoonlike gebruik. Met die totstandkoming van die Uraanverrykingskorporasie het hy 'n swart Chevrolet gekry en 'n chauffeur: John Chapman, wat die bynaam Friday gekry het omdat hy benewens sy motorbestuurpligte ook vir dr. Grant ander take behartig het. Dr. Grant het soggens by my bushalte verby gery en my dikwels opgelaai; dit het 'n geleentheid gebied om projeksake te bespreek.

Die oortydbusdiens was nog 'n logistieke nagmerrie. Die passasiers is vanaf Pelindaba tot by Pretoria-Wes in vyf-entwintig-sitplekbusse vervoer. Hulle het daar oorgeklim op 
mikrobusse, en party nog 'n derde keer na motors. My rit het bestaan uit die bussie vanaf Pelindaba tot in Pretoria-Wes, mikrobus na die Pretoria Stasie vir diegene wat die trein gehaal het, en dan verder suid in 'n Landrover wat oom Jack van der Merwe bestuur het. Die Landrover het deur die suidelike voorstede getoer en my laaste in Monumentpark afgelaai. Saans sou hierdie laaste rit Irene en Lyttelton insluit.

Die gemiddelde personeellid het twee ure per dag op die bus deurgebring, met ander woorde omtrent 450 uur per jaar. Hoe het hulle hierdie tyd benut? Party het geslaap, party het gelees, reëlings kon getref word met die busbestuurder om koerante te koop, party het gestudeer en ander het sommer gesels. 'n Groep op een van die busse het die agterste sitplek gebruik en op 'n opvoutafel kaart gespeel.

Die stories en gebeure op die busse tydens die sewentien jaar wat ek 'n passasier was, kan op sigself 'n boek regverdig. Ongelukkig is al die stories nie aangenaam nie. Die nou kronkelpad tussen Pretoria en Pelindaba was as 't ware die pad van die dood. Daar was etlike noodlottige en byna noodlottige ongelukke, waarby busse betrokke was.

\section{DIE VERGADERINGS VAN DIE GASVERKOELING- PROJEK}

'n Uiters belangrike aspek van die projek was die projekvergaderings wat weekliks op Vrydae om 09:00 in dr. Grant se kantoor plaasgevind het. Benewens dr. Grant het die GVPkomitee bestaan uit dr. Conrad Johannes (metallurg), dr. Immo Bock (wetenskaplike), Bill Grant (laboratorium), dr. Hannes Human (later opgevolg deur Sakkie Labuschagne) (administrasie en aankope), Jan Rijneke (werkwinkel) en Felix Bosch (ontwerpkantoor). Dr. Jan Wannenburg (kompressors) het ook later 'n permanente lid van die komitee geword. Wanneer nodig is ander persone ook betrek, soos byvoorbeeld dr. Daan Kemp (chemies) en dr. Noel Pienaar (metallurgies).

Dr. Grant het gewoonlik die vergaderings geopen met 'n oorsig van die week se prestasies en probleme, vordering met die toetse en ander belangrike projekverwante inligting. Elke groepleier het dan geleentheid gekry om verslag te doen oor die week se aktiwiteite. Sake soos werkladings, toerusting, materiaaltekorte of niebeskikbaarheid, is bespreek. Nuwe opdragte vir die verskeie groepe is bespreek. Hierdie vergaderings het heelwat verskil van die klassieke model van 'n projekvergadering. Geen sakelyste of agendas is voor die vergaderings beskikbaar gestel nie, so ook nie notules na die vergaderings nie. Dr. Grant het gedurende die vergaderings alles sorgvuldig in 'n A5-notaboek met 'n spiraaldraadbinding opgeskryf. Die rekord van die GVP was dus saamgevat in 'n reeks van hierdie notaboekies. Daar is wel in die later stadia van die projek verslae saamgestel oor verskillende aspekte van die projek. Hierdie verslae is meestal streng vertroulik en die verspreiding beperk op 'n nodig-om-te-weet-basis.

\section{DIE TOETSE MET URAANHEKSAFLUORIED (UF $\left.{ }_{6}\right)$ BEGIN}

Die aanvanklike eksperimentele werk op die draaikolkskeidingselemente is met ligte gasse, soos byvoorbeeld argon, kripton, neon en xenon uitgevoer. Hierdie gasse is niereaktief en kan maklik hanteer word. Vir uraanverryking moet uraanheksafluoried $\left(\mathrm{UF}_{6}\right)$ gebruik word, omdat dit die enigste uraanverbinding is wat by drukke en temperature naby atmosferies gasagtig is. Dit is 'n uiters giftige en korrosiewe gas, wat in die teenwoordigheid van die waterdamp in die lug, hidroliseer om hidrofluoorsuur (HF) te vorm. Hidrofluoorsuur is een van die aggressiefste stowwe bekend; aanraking met menslike weefsel beteken gewoonlik dat die beskadigde weefsel chirurgies verwyder moet word. Inaseming van $\mathrm{UF}_{6}$ is gewoonlik noodlottig. Om dié rede moes al die $\mathrm{UF}_{6}$-toerustig helium-lekdig wees - 'n vereiste wat baie moeilik is om na te kom. Teoretiese studies het bewys dat die isotoopskeidingsvermoë van die draaikolkbuis hoër sou wees as die $\mathrm{UF}_{6}$ verdun word met 'n laemassa-draergas, soos waterstof of helium.

Die eerste pogings om $\mathrm{UF}_{6} / \mathrm{H}_{2}$ gasmengsels te gebruik was rampspoedig. Die gas het met die kompressordele gereageer en hulle besoedel - in die proses is die gas ook opgeneem in die besoedelingsprodukte en omgesit in HF. 'n Verdere komplikasie was dat die gasmengsel die glasbuise van die dobbertipevloeimeters geëts en ondeursigtig gemaak het. Om toetse met $\mathrm{UF}_{6}$ te kan uitvoer sou die laboratorium met geskikte toerusting ingerig moes word.

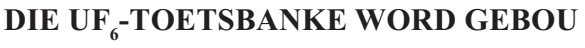

Die belangrikste komponent van die toetsbank was die kompressor. Dit moes eerstens olievry en tweedens lekvry wees. Sodanige kompressors was nie vrylik plaaslik beskikbaar nie, alhoewel die chemiese bedryf wel kompressors ingevoer het vir gebruik met korrosiewe gasse en voedselprodukte. Die projek het 'n Corblin-diafragmatipe kompressor, met 'n vlekvryestaalkop en 'n monel-diafragma gekry. Hierdie kompressor het teen 'n lae spoed heen en weer gegaan en dus 'n doef-doef-doef-geluid en voelbare skokke soos hamerslae veroorsaak. Om hierdie redes was dit nodig om die kompressor op sy eie fondasie te laat staan en nie op die gebou se vloer nie. ' $n$ Gat is deur die kompressorkamer (die kelder) se vloer gekap, en 'n massiewe betonblok met baie staalstawe gegiet om die skokke te demp.

Die Corblin-kompressor het sekere inherente probleme gehad; eerstens het die diafragma as gevolg van metaalvermoeidheid 'n beperkte leeftyd gehad, en indien die diafragma sou breek sou die totale toetsopstelling besoedel word, wat deeglike skoonmaak sou vereis. Om 'n diafragma te vervang was 'n tydsame proses wat toetstyd verkwis het.

Die eksperimentele werk het vereis dat die molekulêre massas van die komponente van die $\mathrm{UF}_{6} / \mathrm{H}_{2}$ gasstroom akkuraat bepaal moes word. Op hierdie tydstip was daar geen instrument beskikbaar om sodanige parameters te bepaal nie. Dr. Grant het 'n briljante idee gekry. Nadat hy na 'n traporreltjie in die kerk geluister het, het hy besef dat die frekwensies van die note 'n funksie was van die eienskappe van die lug in die pype. Indien die individuele frekwensies van vibrasie van die komponente van 'n gasmengsel bepaal kon word, sou dit die verhouding van die komponentmolekule gee. Hierdie effek word byvoorbeeld waargeneem wanneer 'n persoon sy longe vol helium trek, en as hy dan praat - soos Donald Duck klink omdat stembande in helium teen ' $n$ ander frekwensie vibreer as wat die geval is met lug. Hierdie beginsel is suksesvol toegepas en in die verrykingsaanlegte wat later opgerig is, is letterlik honderde van hierdie "fluitjiesmeters" gebruik.

Die toetse met $\mathrm{UF}_{6}$ kon nou in alle erns voortgaan. Die werkwyse was soos volg: 'n Eksperimentele draaikolkskeidingsbuis is deur die wetenskaplikes ontwerp, daarna is die ontwerp deur die ontwerpkantoor omgesit in werkstekeninge met die nodige afmetings en parameters, sodat die instrumentmakers dit kon maak. Die probleme verbonde aan die daarstel van 'n skeidingselement moet geensins onderskat word nie. Slegs uitgesoekte en puik vakmanne kon hierdie taak uitvoer. Dit was nog voor die era van rekenaars en berekeninge van hoeke en lengtes is nog in meeste gevalle met logaritmes 
en trigonometriese tabelle gedoen. 'n Wang-rekenaar met twintig terminale is wel later aangekoop, maar as al twintig terminale beset was, was dit vinniger om logaritmes te gebruik. Nadat 'n buisopstelling deur die tegnici getoets is, is die eksperimentele lesings sorgvuldig ontleed. Wysigings aan die buis is dan voorgestel en nuwe komponente gemaak. Dr. Grant se insette na die ontwerpkantoor was gewoonlik voorsien van die verwagte gasvloeipatroon van die komponente, geteken in vier verskillende kleure met rolpuntpenne. Die vloeipatrone het soos vlinders gelyk en gevolglik het die draaikolkskeidingselemente die bynaam "vlinders" gekry; dit was dus nie, soos 'n sekere skrywer onlangs in 'n artikel beweer het, deel van 'n sinistere geheime taal wat gebruik is nie.

\section{DIE TOPVLAK VAN DIE GASVERKOELINGPROJEK}

Die toppersoneel van die gasverkoelingspan se bydraes aan die projek moet nie onderskat word bloot omdat hierdie manne se werk minder sigbaar was nie. Dr. T.E.W. Schumann, ten tye van die projek adjunkvoorsitter van die Raad, het saam met dr. A.J.A. Roux op regeringsvlak onderhandel om die toestemming en nodige fondse te verkry vir die projek om voort te gaan. Dr. Schumann het eenkeer 'n ontwerpkonsep vir 'n skeidingselement ingedien vir vervaardiging en toets.

$\mathrm{Na}$ my beskeie mening was die belangrikste suksesfaktor van die gasverkoelingprojek sonder twyfel die leierskap van $\mathrm{dr}$. Wally Grant, met sy helder insig, goeie beplanning, deeglike navorsing, en sorgvuldige analise van alle eksperimentele werk. Die spanlede was gemotiveerd om te alle tye hulle beste te lewer. As mensekenner het Doc Wally omgegee vir sy personeel. Ek het dit geweldig waardeer dat Doc Wally ten spyte van 'n uiters druk program, tyd afgestaan het om my huweliksbevestiging by te woon, en dit terwyl sy vrou Anna enige tyd kraaminrigting toe moes gaan.

\section{KOMPRESSORONTWIKKELING}

Kompressors is naas die skeidingselemente seker van die belangrikste komponente in 'n verrykingsaanleg, en gevolglik is kompressorontwikkeling betreklik vroeg aangepak. Mnr. (later doktor) J.J. (Jannie) Wannenburg, oudlektor in lugvaartkunde aan die Universiteit van Stellenbosch, is aangestel as hoof van kompressorontwikkeling (1965). Soos vroeër genoem, is die twee belangrikste vereistes vir sodanige kompressors dat hulle lekvry na die atmosfeer en olievry moet wees.

Ek het dr. Wannenburg bygestaan met die ontwerp van prototipe kompressors. Die eerste prototipe was basies 'n standaardkompressor van die tipe wat in motorhawes gebruik word om bande te pomp. Die kompressor is voorsien van 'n bykomstige huls en kruiskop. Die stang is afgedig deur middel van 'n blaasbalk gemaak van 'n aantal ringvormige vlekvryestaalplaatjies waarvan die rante aanmekaar gesweis is. Dit het gewerk, maar met die beweging het die kronkelinge van die blaasbalk teen mekaar geklap. Om dit te verhoed is rubberbuis in die lengte oopgesny en buite om elke kronkel gesit. Dit het die probleem opgelos en die kompressor het gewerk. Ons sou 'n honderd ure se werking van hierdie eerste prototipe as sukses beskou het.

Die dag het aangebreek toe die kompressor die teiken honderd ure se werking sou voltooi het. Bier en eetgoed is gekoop, en op die gegewe tyd het die groep bymekaar gekom. Die kompressor is afgetakel en - tot ons groot teleurstelling moes ons sien dat die blaasbalk oral op die sweisnate, as gevolg van vermoeidheid, gebreek het, en dat die plaatjies slegs deur die rubberbuis aanmekaar gehou is. Die partytjie het voortgegaan, maar ongelukkig nie om sukses te vier nie.

Om die olievrye werking te ondersoek is die gietystersuierringe van die kompressor met ringe van 'n plastiese materiaal met 'n betreklike lae skuifspanning vervang. Dié materiaal, politetrafluooretileen (PTFE), was pas vrygestel en is bemark deur Imperial Chemical Industries (ICI) van Engeland as TEFLON, en deur Du Pont van Frankryk as FLUON. Aangesien dit ' $n$ betreklike nuwe materiaal was, was min tegniese gegewens vir die ontwerper beskikbaar. Ons het wel geweet dat dit 'n goeie elektriese en termiese isolator was, dat dit gebruik kon word vir busse waar geen smering gebruik kon word nie, en ons het ' $n$ idee gehad van die liniêre uitsettingskoëffisiënt. Die idee was dat sodra die suierring 'n paar keer oor die silinderwand beweeg het, sou van die teflon op die wand afgesmeer het, en dan sou dit teflon op teflon wees wat baie goed sou wees. Die plaaslike agente kon slegs plaatmateriaal van $6,35 \mathrm{~mm}$ dikte voorsien.

Ons het ' $n$ teflonstrook die wydte van die ringgroef, gebuig om 'n ring te vorm, die punte van die ring is op die middellyn gehalveer op teenoorgestelde kante, om 'n oorslaglas te vorm met $3 \mathrm{~mm}$ splete. Volgens 'n literatuuroorsig wat destyds uitgevoer is, is dit die eerste keer wat daar probeer is om teflon vir hierdie doel aan te wend. Die kompressor het goed gewerk, maar slegs vir omtrent tien sekondes, voordat die suier vasgeslaan het. Ons vermoede is bevestig, die liniêre uitsettingskoëffisiënt was baie hoër as wat ons verwag het, en as gevolg van die swak termiese geleiding van teflon het die ring baie meer uitgesit as wat ons verwag het en die suier vasgeknyp. Groter splete het dié probleem opgelos en die kompressor kon aanhoudend werk.

'n Hoeveelheid teflonpoeier is van die plaaslike agente verkry. Die poeier is gemeng met $20 \%$ (per volume) bronspoeier en in 'n vorm onder die voorgeskrewe hoë druk gepers om 'n strook te vorm. Daarna is die materiaal eers gesinter. Die volumeverhouding hier ter sprake was 9:1. Die byvoeging van die bronspoeier het die termiese geleiding van die suierring heelwat verbeter. Hierdie tipe suierring is hierna met groot welslae gebruik. Skroeftipe-kompressors is ook ondersoek as 'n verdere opsie, maar verwerp ten gunste van die suierkompressors.

\section{GESONDHEIDSGEVARE EN PROJEKVEILIGHEID}

Nieteenstaande die feit dat die gesondheidsgevare van die projek meestal van 'n toksiese en geensins van 'n stralingsaard was nie, is die projeklede beskou as stralingswerkers. Urine- en bloedmonsters is gereeld ondersoek, borskas X-strale is elke ses maande geneem, asook gesigsveldtoetse. Benewens hierdie toetse is daar ook 'n jaarlikse heelliggaamtelling uitgevoer. Die heelliggaamteller was geleë by die destydse H.F. Verwoerdhospitaal. Die teller was gemonteer op 'n stellasie wat stadig bokant die persoon, van kop tot toon, beweeg het, sodat die hele liggaam ondersoek is; dit het omtrent negentig minute geduur. Die tellings van die hele spektrum is dan op 'n grafiek gestip. Onlangse blootstelling aan radioaktiwiteit, en die spesifieke element, word dan daarop aangedui.

Minder ernstige hidrofluoorsuur-brandwonde is met kalsiumbikarbonaat behandel, ernstiger gevalle moes hospitaalbehandeling ontvang. Alle veiligheids- en noodtoerusting sowel as beskermende klere was in die laboratorium beskikbaar, en die gebruik daarvan is gemoniteer deur die destydse veiligheidsbeampte, Hendrik Boshoff. Twee verpleegkundiges, susters Pieterse en Kell was voltyds en 'n medikus was deeltydss beskikbaar in die ten volle toegeruste mediese sentrum op die Pelindaba-terrein. Minder ernstige noodgevalle en roetine- 
ondersoeke is in die sentrum uitgevoer. Vir ernstige noodgevalle was 'n moderne paralans te alle tye beskikbaar om pasiënte na die hospitaal te vervoer.

Die projek het 'n baie goeie veiligheidsrekord gehandhaaf, en slegs enkele gevalle wat hospitaalbehandeling vereis het, het plaasgevind.

\section{DIE TOETSE MET UF ${ }_{6}$ GAAN VOORT}

Die skeidingstoetse het vereis dat gasmonsters geneem moes word vir ontleding om die isotoopkonsentrasies deur middel van 'n massaspektrometer te bepaal. Met die ligte gasse was dit betreklik maklik; glasmonsterbuise met glaskrane is gebruik om die monsters te trek vir analise. Mosterneming in die geval van $\mathrm{UF}_{6}$-toetse, was meer ingewikkeld. 'n Opstelling is deur die tegnici aanmekaar gesit om die monsters te neem. Dit het bestaan uit 'n dubbele klep met twee pypies, wat aan die end van 'n klein silindriese tenk omtrent $30 \mathrm{~mm}$ deursnee, ingesweis is. Twee pypies van die ander koppelpunte van die twee kleppe is deur koppelstukke aan die toetsbank verbind. Om 'n monster te neem moes die gas deur die pypies en die tenk vloei. Die tenk is dan in 'n fles vloeibare stikstof ondergedompel, om die gasmonster solied te vries. Die kleppe is dan toegedraai, die koppelstukke losgemaak, en die monster na die massaspektrometer geneem vir analise. Vir die ontleding is die monsterapparaat aan die massaspektrometer gekoppel, die tenkie is deur middel van verhittingsband verhit om die gas weer vloeibaar te maak en die analise uitgevoer.

Dié gasmonster-ontledingsmetode het 'n paar keer goed gewerk, maar toe vind 'n onverwagte voorval plaas. Terwyl die monsterapparaat met die verhittingsband verhit word, tydens die analise van 'n gasmonster op die massaspektrometer, het 'n ontploffing plaasgevind en die kenmerkende wit wolk van 'n $\mathrm{UF}_{6}$-vrystelling het verskyn. Die laboratorium is onmiddellik ontruim en die vier tegnici wat in die nabyheid van die ontploffing was, is hospitaal toe geneem. Gelukkig is hulle na waarneming ontslaan, sonder enige nadelige gevolge. Dit was 'n terugslag vir die projek.

Nadat die monsterapparaat deeglik chemies gereinig is, is dit ondersoek, en 'n dinkskrum wat deur die projekkomiteelede bygewoon is, is gehou. Die oorsaak van die ongeluk was voor die hand liggend. Dit is veroorsaak deur foutiewe sweisvoorbereiding op die deksels van die tenkie. Die voorbereiding met skerp rante het hoë spanningkonsentrasies veroorsaak en die deksel het geswig. Die tenkie het gelyk soos 'n melkblikkie wat oopgesny is.

$\mathrm{Na}$ etlike ure se bespreking en oorweging van verskeie voorstelle, is my idee vir 'n monsterbottel aanvaar. Dié idee was om die pyp in die vorm van 'n U te buig, en nie 'n tenkie te gebruik nie. Op dié wyse is sweisnate uitgeskakel. Die U-buis kon dan maklik in die fles met die vloeibare stikstof geplaas word. Dr. Grant was baie ingenome met my voorstel vir die monsterbottel, en dié middag het ek nie met die bus huis toe gery nie, maar op uitnodiging saam met Doc Wally in sy groot swart motor. By my huis het hy saam met my voordeur toe gestap. Dit was 'n gebaar wat vir my baie beteken het en my aan die woorde van Harry Haigh, personeelbeampte van YSKOR (1954) herinner: "Die ware kenmerk van 'n groot man, is 'n man wat klein manne laat groot voel"

\section{DIE DEURBRAAK EN SUKSES}

'n Besoek aan die gasverkoelingsprojek deur die destydse Eerste Minister, dr. H. F. Verwoerd, is beplan vir November 1965. Die datum van hierdie besoek, wat etlike maande tevore geskeduleer was, was dan ook die teikendatum om die skeiding van ${ }^{235} \mathrm{U}$ - en ${ }^{238} \mathrm{U}$ - isotope deur middel van die draaikolkbuis suksesvol te bewerkstellig.

'n Week voor die beplande besoek van die Eerste Minister, het daar wel 'n mate van skeiding plaasgevind, maar dit kon nog nie as sukses beskou word nie. Vir die volgende week het die navorsingspan letterlik dag en nag gewerk. Slegs 'n dag voor die beplande besoek het die deurbraak plaasgevind - die oomblik van waarheid - DIE GROOT SKEIDING! - dit is sonder twyfel bewys dat die skeidingselement ${ }^{235} \mathrm{U}$ - en ${ }^{238} \mathrm{U}$-isotope in 'n $\mathrm{UF}_{6}$ - He mengsel kon skei.

Die besoek het soos beplan plaasgevind, dr. Verwoerd is eers ingelig oor die vordering met die projek, daarna het hy die laboratoria besoek, en laastens is hy aan al die spanlede voorgestel. Dit was 'n groot oomblik in die geskiedenis, maar vir my persoonlik, was dit sonder twyfel een van die hoogtepunte van my lewe.

Vyf jaar na die deurbraak is erkenning aan sekere lede van die gasverkoelingspan verleen. Hulle was dr. A.J.A. Roux, dr. W.L. Grant, dr. J.W.L. de Villiers, dr. C. Johannes, dr. J.J. Wannenburg, dr. J.J. Human, dr. R.S. Loubser, mnr. B. von M. Louw, mnr. Jan Reyneke, mnr. W.W. Grant, mnr. F.W.L. Bosch, en mnr. R. Sinclair. Die geleentheid was 'n ete in die uraankamer van die President Hotel in Johannesburg, op 9 Desember 1970, waartydens die destydse speaker van die parlement Sy Edele Henning J. Klopper as gasheer opgetree het. 'n Aantal genooide gaste (waaronder mnr. Brand Fourie, Departement Buitelandse Sake, en dr. J.G. Loubser, hoofbestuurder Suid-Afrikaanse Spoorweë) was ook teenwoordig. Die bewoording van die uitnodiging - “...as blyk van waardering vir hul dienste in belang van Suid-Afrika" - het sekerlik elke spanlid laat trots voel om 'n Suid-Afrikaner te wees. Die hoofdis op die spyskaart van hierdie glansryke funksie was forel met botter en neutsous. Ek is trots dat die eer om 'n aandeel aan die gasverkoelingprojek te kon gehad het, my te beurt geval het, en dat ek ook die voorreg gehad het om onder leiding van 'n wetenskaplike van wêreldformaat, in die persoon van dr. Grant, te kon gewerk het. 